\title{
Review of techological methods and experimental determination of thermodynamic and transport properties of reagents for carbon dioxide removal from flue gases
}

\author{
Vuk D. Spasojević ${ }^{1}$, Slobodan P. Šerbanović ${ }^{2}$, Predrag Stefanović ${ }^{1}$, Mirjana Lj. Kijevčanin ${ }^{2}$ \\ ${ }^{1}$ Institute for Nuclear Sciences „Vinča“, University of Belgrade, Mike Petrovića Alasa 12-14, Belgrade, Serbia \\ ${ }^{2}$ Faculty of Technology and Metallurgy, University of Belgrade, Karnegijeva 4, Belgrade, Serbia
}

\begin{abstract}
In this work a review of the currently available methods for carbon dioxide removal from flue gasses is given. Some of them are commercially available, while others are still under development. Special attention is given to detailed description of the methods based on hemi sorption by aqueous solutions of alkanolamines, which found wide commercial use in industry. Selection of appropriate absorbent, process equipment, methods, working parameters, combustion processes, etc., are some of the key points that will be reviewed within this work in order to present advantages and limitations of carbon dioxide removal methods. In the experimental section we have provided data on density, viscosity and refractive index of insufficiently investigated carbon dioxide removal agents, such as monoisopropanolamine (MIPA), diisopropanolamine (DIPA), triisopropanolamine (TIPA) and currently widely used dietanolamine (DEA). The data obtained are crucial for the equipment design and process optimization.
\end{abstract}

Keywords: density, viscosity, refractive index, carbon dioxide removal, hemisorption, flue gases, alkanolamines.

\section{SCIENTIFIC PAPER}

UDC 66.081.4:66.07:502/504

Hem. Ind. 68 (1) 123-134 (2014)

doi: 10.2298/HEMIND130312039S

Available online at the Journal website: http://www.ache.org.rs/HI/

In order to reduce the green house gases (GHG) emission, it is necessary to use adequate prevention measures, which have to comprise efforts in energy sector, industry, commerce and transport. In general, it could be assumed that over $40 \%$ of the worldwide carbon dioxide $\left(\mathrm{CO}_{2}\right)$ emissions are caused by electricity generation in fossil fuel power plants. Climate changes are affecting weather systems causing negative impacts on human health, agriculture, and global economy. This resulted in serious environmental concerns and the need to reduce GHG emissions from industrial resources. $\mathrm{CO}_{2}$ has the largest ratio in the world's annual emissions of GHG's. Reduction of $\mathrm{CO}_{2}$ emissions from industrial waste gases have become major target. Before laboratory applications or industrial equipment installation, it is a common practice nowadays that process simulation is carried out using software specially designed for these purposes. However, majority of process simulators such as ChemCad, ASPEN PLUS and computational fluid dynamic software (Fluent, ANSYS, etc.) use constant values of pure component properties, independent of temperature and concentration. This leads toward the use of this data in narrow temperature or concentration range. If a real process

Correspondence: M.Lj. Kijevčanin, Faculty of Technology and Metallurgy, University of Belgrade, Karnegijeva 4, Belgrade, Serbia.

E-mail: mirjana@tmf.bg.ac.rs

Paper received: 12 March, 2013

Paper accepted: 8 May, 2013 exceeds these ranges, significant calculation errors can occur, thus providing false overall process equipment design. In order to contribute to the requirements of realistic and reliable thermodynamic and transport property data, the series of experiments were conducted using four pure alkanolamines. Alkanolamines, as weak bases, are usually used for acid gasses absorption. In this paper, densities, refractive indices and viscosities of monoisopropanolamine (MIPA), diisopropanolamine (DIPA, triisopropanolamine (TIPA) and diethanolamine (DEA), were measured in the temperature range $288.15-333.15 \mathrm{~K}$ and at atmospheric pressure. Obtained data is important for understanding the nature of chemical bonds within alkanolamines and their mixing effects, but also relevant for the process design and optimization. Fortunately, all software packages previously mentioned offer possibilities for the implementation of experimental data, introducing different parameters through custom builtin user defined functions.

\section{REVIEW OF CARBON DIOXIDE CAPTURE TECHNOLOGIES}

Primary goals for the carbon dioxide capture technologies were actually established for the use in other industries, rather than for the mitigation of green house gases. Nevertheless its contribution to carbon capture field development is undisputable. Industrial implementation of these technologies was set mainly 
on the purification of gases emitted from petrochemical and oil industries or, on the generation of derivates that can be synthesized and effectively used for other purposes. In early 1990's the first pilot plants and large laboratory installations emerged with the task of $\mathrm{CO}_{2}$ removal from flue gases. As worldwide attention increased with clear connection between negative effects on climate change and increase of the concentration of $\mathrm{CO}_{2}$ in atmosphere, international community set main rules and emission quotas for different gases that contribute to the green house effect. This key point opened up opportunities for the commercialization of emission quotas trading system followed by increase of investments in development of $\mathrm{CO}_{2}$ removal technologies. During the past ten years, full scale industrial units were implemented in USA and Germany as the world leaders in this field.

Nowadays, there are numerous technologies for treatment of flue gases. Currently, there are three main routes for the development of the $\mathrm{CO}_{2}$ removal process that are presented in Figure 1 . The first process includes $\mathrm{CO}_{2}$ capture from the flue gas stream after combustion (Post-combustion). The other process includes the $\mathrm{CO}_{2}$ capture from the reformed synthesis gas of an upstream gasification unit (Pre-combustion). The newly developed technique for combustion uses nearly pure oxygen instead of air thus increasing the $\mathrm{CO}_{2}$ concentration within flue gases stream (Oxyfuel). All the main principles of the above mentioned techniques are presented in Figure 2.

Listed processes require additional energy input for gas separation, regeneration of absorbents, capture, conditioning, storage and transportation of the $\mathrm{CO}_{2}$. It is clear that the negative side effect of the $\mathrm{CO}_{2}$ removal is the decrease of energy efficiency of power plants from 10 to $14 \%$. In the post-combustion process the efficiency loses are from 10 to $12 \%$ [1], while they reach $10 \%$ for the oxyfuel process [1]. There is signi-

Post combustion

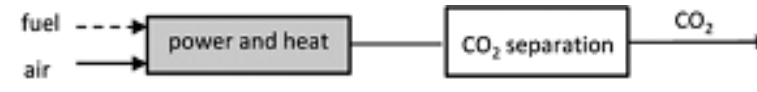

Oxyfuel

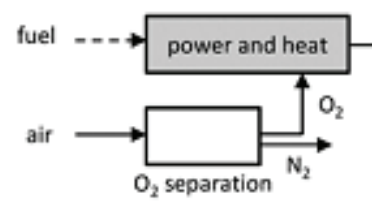

Pre combustion
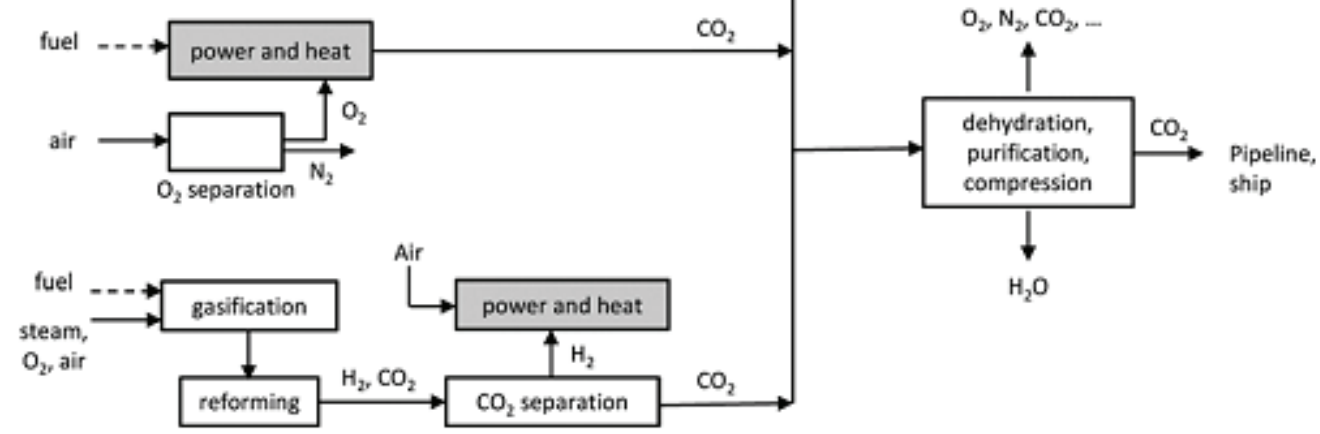

Figure 1. Main routes of development of the $\mathrm{CO}_{2}$ removal technologies.
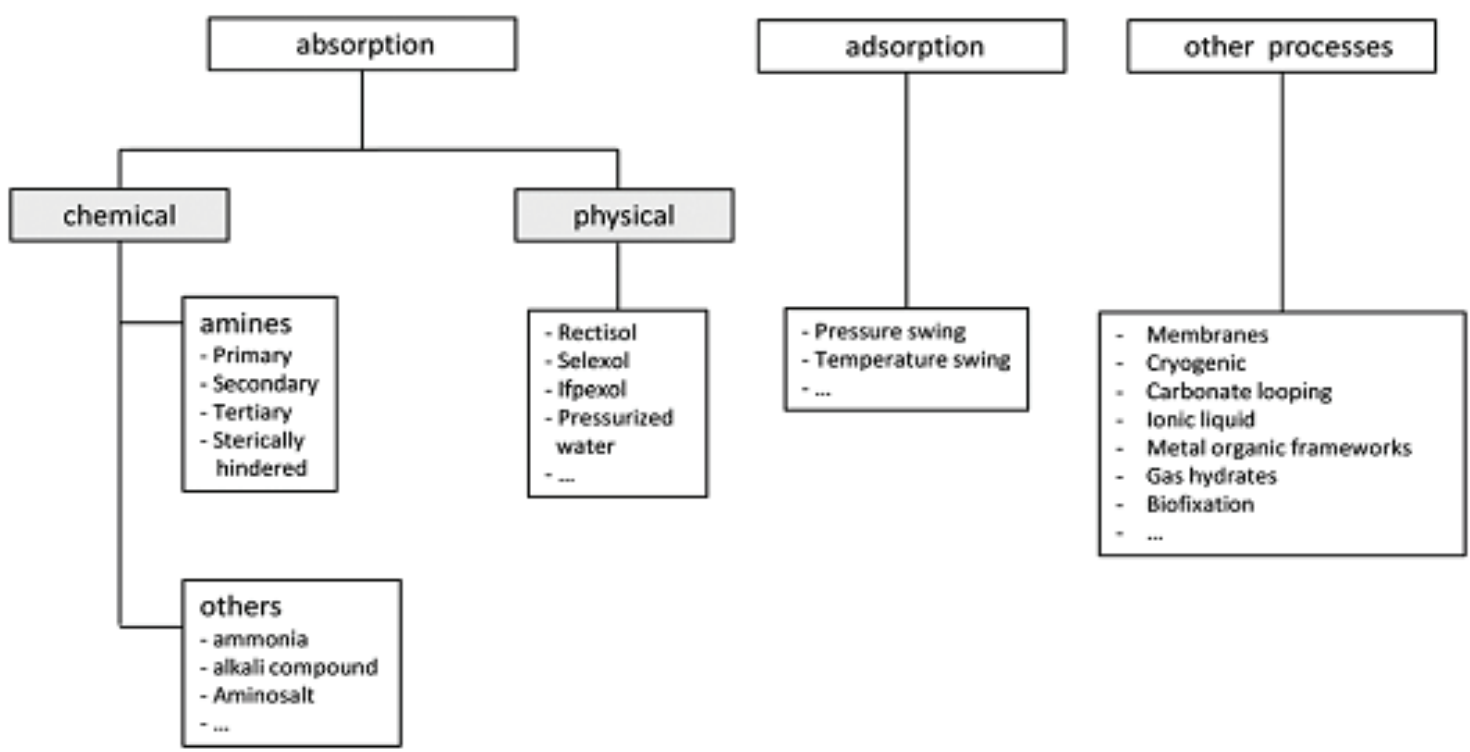

Figure 2. Main principles of carbon dioxide capture in use or under development. 
ficant potential for reduction in energy requirements for the carbon dioxide removal. The largest amounts of energy are needed for the absorbent regeneration (around $60 \%$ of overall energy requirement) and additional $20-30 \%$ are spent for the compression, storage and transportation of $\mathrm{CO}_{2}$. In this respect, new research data show promising results for the use of socalled sterically hindered amines and their blends characterized by increased loading capacity for $\mathrm{CO}_{2}$ and simultaneous decrease in energy requirements for their regeneration [2,3]. Additional savings could be made by the use of waste heat (heat loses from cooling of flue gases before the entry point into $\mathrm{CO}_{2}$ removal plant, but also heat gains from the exothermic reactions between absorbents and flue gases). Efficiency loses of $8 \%$ are feasible and could be easily achieved in the near future.

\section{Pre-combustion processes}

Two dominant pre-combustion technologies are the production of synthesis gas and pressure swing adsorption (PSA). The first process includes partial oxidation of fuel in gasification unit and the generation of $\mathrm{CO}$ rich stream. After the gasification, through the catalytic COshift reaction, $\mathrm{CO}$ reacts with steam as oxidant where $\mathrm{CO}_{2}$ and $\mathrm{H}_{2}$ rich stream is generated. Since such generated fuel gas is under high pressure and has a high content of $\mathrm{H}_{2}, \mathrm{CO}_{2}$ removal methods based on physical adsorption become advantageous.

This process requires additional cleaning of synthesis gas (from ash particles, alkali and sulfur components and other impurities). That could be accomplished using air separator unit prior gasification unit. The $\mathrm{CO}_{2}$ capture takes place after the conversion of $\mathrm{CO}$ into $\mathrm{CO}_{2}$ and $\mathrm{H}_{2}$ and generation of fuel gas. Such decarbonized fuel gas is then directed to the combined gas and steam turbine cycle for generation of electricity. Overall process of integrated gas coal cycle (IGCC) plant with $\mathrm{CO}_{2}$ capture is given in Figure 3.

Pressure swing adsorption method uses physical adsorbents such as carbon, zeolites or alumina [4], which selectively absorb $\mathrm{CO}_{2}$ while flue gas passes through layers of beds. Process consists of two step cycles. In the first step, adsorbent selectively adsorbs $\mathrm{CO}_{2}$ from feed gas, under high pressure conditions, while in the second step, $\mathrm{CO}_{2}$ is removed from adsorbent by reduction of pressure, thus enabling regeneration of adsorbent and its use in the next cycle. Beside the production of synthesis gas and PSA methods, scrubbing procedure with physical sorbents can be used, offering the possibility for simultaneous removal of $\mathrm{H}_{2} \mathrm{~S}$ and $\mathrm{COS}$. Methanol based solvents could be effectively used for scrubbing of fuel gases and easily regenerated using nitrogen and applying temperature change. Positive side of the scrubbing process is that $\mathrm{CO}_{2}$ can be removed together with $\mathrm{H}_{2} \mathrm{~S}$ and COS. Disadvantage is the necessity for high pressure operating conditions which limits the use of the aforementioned technologies in pulverized coal power plants, operating at lower pressures.

Evaluation of the use of IGCC technology shows some clear advantages and disadvantages regarding the $\mathrm{CO}_{2}$ removal. Advantages are: high efficiency potential and generation of electricity and hydrogen. Synthesis gas could be effectively used for the production of other chemicals and fuels (methanol, hydrogen for fuel cells), leading to greater flexibility, higher plant utilization and reduction of operating costs. Huge

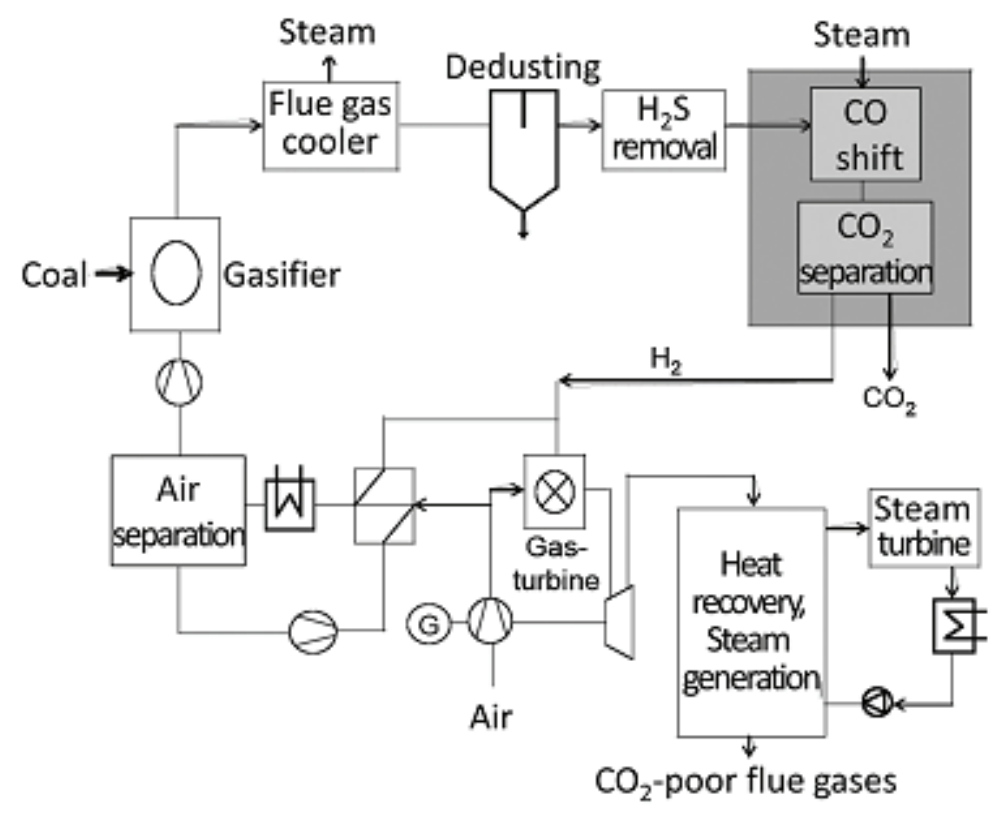

Figure 3. IGCC power plant with carbon dioxide capture. 
investments, operational and maintenance cost followed by technical shortfalls manifested through long startup periods are some of the disadvantages, which drove much of the current research attention. With 5 operational IGCC power plants in the world [5] and plans for construction of new power plants in England and Canada based on oxyfuel combustion technology, significant contributions are made towards improving the process efficiency and reduction of operational costs.

\section{Oxyfuel process}

The oxyfuel process uses stream of pure oxygen for combustion of coal. Flue gases, after cleaning and washing, consist of high $\mathrm{CO}_{2}$ concentration (around 90 vol.\% ), compared to the conventional power plants (7-15 vol.\%). Such pure $\mathrm{CO}_{2}$ stream could be easily compressed and transported to storage site after being demoisturized. Supply of pure oxygen stream is achieved by "gas to liquid" cryogenic air separation units (at temperatures around $-180{ }^{\circ} \mathrm{C}$ ). Currently, the largest planned unit for generation of pure oxygen can supply about $800000 \mathrm{~m}^{3} / \mathrm{h}$ [6]. Taking into account that 500 $\mathrm{MW}$ unit with efficiency of $43 \%$ requires about 270000 $\mathrm{m}^{3} / \mathrm{h}$ of pure oxygen according to stoichiometry, great attention must be given to the development of new methods that will assure steady and continuous supply of pure oxygen with reasonable operating costs.

The combustion process with stream of pure oxygen causes the altering of temperature within steam generator unit. Change in temperature must be limited due to the limitations in properties of applied materials in combustion chamber. In order to achieve this, large portion of $\mathrm{CO}_{2}$ rich stream (around two-thirds of flue gases volume flow) is directed back to combustion chamber. The entire process is presented in Figure 4.

The problems yet to be solved include several improvements: of air separation method and units, of the steam generator and of the processes of denitrification and desulfurization. Air separation unit consumes the largest portion of energy (from overall $10 \%$ energy consumption, $7 \%$ is required for the process of air separation and additional $3 \%$ for the $\mathrm{CO}_{2}$ compression and storage). Current and future development [7] in this field is set on the usage of the mixed ion electron conducting membrane technology and chemical looping technology. Main concept behind the membrane separation technique is the application of ceramic or other advanced materials that show the selective permeability towards different gas components. Air stream at high temperature (above $700{ }^{\circ} \mathrm{C}$ ) passes through the membrane. Membrane selectivity allows only transport of oxygen, preventing other components to pass through it. Present limitations of wider usage of these membranes on large scale industrial units are temperature stability of the membrane and its mechanical strength.

The chemical looping process includes the use of metal oxides for combustion with fuel, instead of pure oxygen. After combustion, these metal oxides are regenerated in another reactor using air, limiting input of nitrogen from air. Current laboratory and pilot scale tests have asset a main goal to identify the most suitable materials as metal oxygen carriers. At this point, these oxygen generation methods are still in early stage of development and can be classified as second generation carbon capture and storage technologies.

Advantages of oxyfuel technology are low environmental impact with high potential for further energy requirements reduction through implementation of new separation methods. On the other hand, different heat and flow conditions require new design of heat exchangers, burner's modification, etc., are clear disadvantages of this technology.

\section{Post-combustion process}

The post-combustion process includes treatment of flue gases after combustion. Most widely used process includes the so-called chemical washing with amine based solvents. Main process includes two columns (an absorber and a stripper column). Flue gases, after pre-

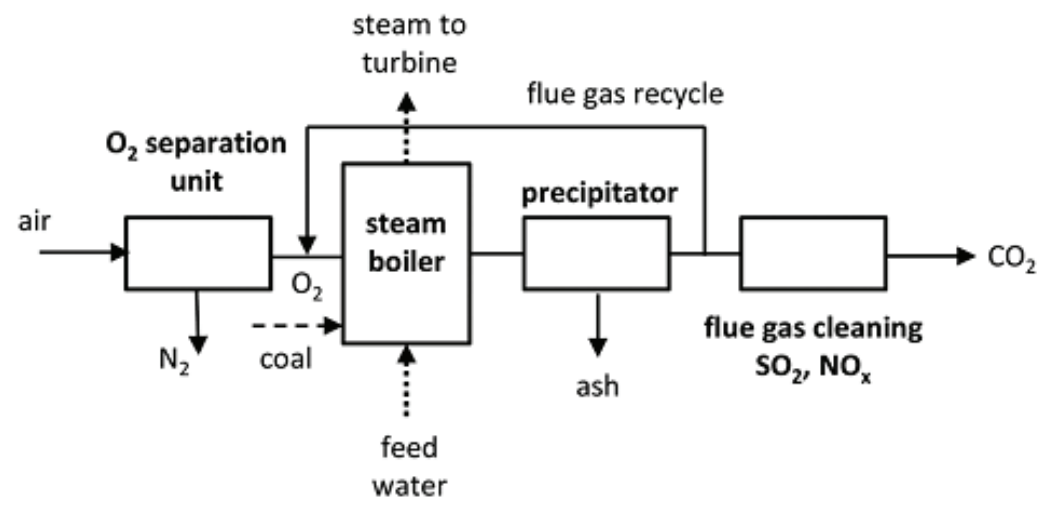

Figure 4. Process flow diagram of carbon dioxide capture with oxyfuel combustion. 
cipitator, are cooled to temperature between $40^{\circ} \mathrm{C}$ and $60{ }^{\circ} \mathrm{C}$. Subsequently, they are introduced into the bottom of the absorption column. Amine based solvent is introduced at the top of the column. Gas-liquid contact is achieved either by tray or packed columns. Bonding of $\mathrm{CO}_{2}$ with amine solvent is accompanied by release of heat. This heat must be effectively removed because of decrease of $\mathrm{CO}_{2}$ solubility in amine solvent with the increase of temperature. $\mathrm{CO}_{2}$ rich stream at the bottom of absorber column is carried to stripper column where, at elevated temperatures around $120{ }^{\circ} \mathrm{C}$, the process of solvent regeneration and release of $\mathrm{CO}_{2}$ takes place. Steam used for this process is taken from low pressure power plant steam, thus reducing the potential for generation of electricity. The chemical bonds between $\mathrm{CO}_{2}$ and amine solvent are broken, thus leaving pure stream of $\mathrm{CO}_{2}(99.9 \%)$ which is taken from stripper column, dried, compressed and transported to storage. Regenerated amine solvent is returned to absorption column after passing through heat exchanger used for preheating of $\mathrm{CO}_{2}$ rich stream. The amine based chemical washing method has some constraints that require additional research efforts. Originally, chemical washing was designed and effectively used for scrubbing of the flue gases from petrochemical industries. High levels of oxygen in the flue gases from power plants can cause amine solvent degradation, which could be prevented by chemical inhibitors. Furthermore, high efficiency of precipitator units must be achieved due to the problems regarding blocking of packed column, which disable the effective operation of process equipment. Levels of gases $\mathrm{NO}_{x}$ and $\mathrm{SO}_{x}$ have to be reduced due to solvent degradation, since they can react with them by salt formation. For example, $10 \mathrm{ppm} \mathrm{SO}_{x}$ is the target concentration upon which the salt formation is avoided [8]. The most challenging problem yet to be resolved is reduction of the energy requirements of stripper column since almost $50 \%$ of overall energy needed for the $\mathrm{CO}_{2}$ capture goes to the process of solvent regeneration. The optimization of the entire process is required so that the thermodynamic limits can be achieved. Recent development offers solvents with significant increase in loading capacity of $\mathrm{CO}_{2}$ and with decrease in energy requirements for its regeneration [9]. Moisture content must also be reduced, since it can cause negative effects on process equipment such as corrosion problems. Integrated system that compensates for all of those effects is presented in Figure 5.

In 2010, post combustion unit started to operate in Germany (Niederaussem site). It is planned to remove $99 \% \mathrm{CO}_{2}$ with less than $10 \%$ energy efficiency loses [10]. Process flow diagram for this unit is presented in Figure 6.

In conclusion, the post combustion carbon dioxide capture process offers some clear advantages such as highest purity of $\mathrm{CO}_{2}(99.9 \%)$ that can be achieved. No fundamental changes of the original power plant process are required, which enables retrofit of the existing power plants. There is also high potential for further improvements and reduction in energy loses by utilization of advanced solvents and overall process optimization. Still, high costs and flexibility of such plants that yet need to be tested, limit the wider use of this method for $\mathrm{CO}_{2}$ removal.

\section{DETERMINATION OF THERMODYNAMIC AND TRANSPORT PROPERTIES OF CARBON DIOXIDE REMOVAL AGENTS}

Determination of transport, physical and chemical properties is crucial in investigation of suitable absorbents for the $\mathrm{CO}_{2}$ removal from flue gases. Data on density, viscosity, vapor pressure, solubility of gases in liquid phases, heat capacities, heat of generations, etc., are some of the data needed for efficient and accurate development of the process and process equipment design. The absorption processes are complex and almost always are followed by multiphase heat, mass and fluid flow transfer. Due to its complexity and variety of potential chemicals that could be used as $\mathrm{CO}_{2}$ absorbents, it is impossible to collect all necessary data

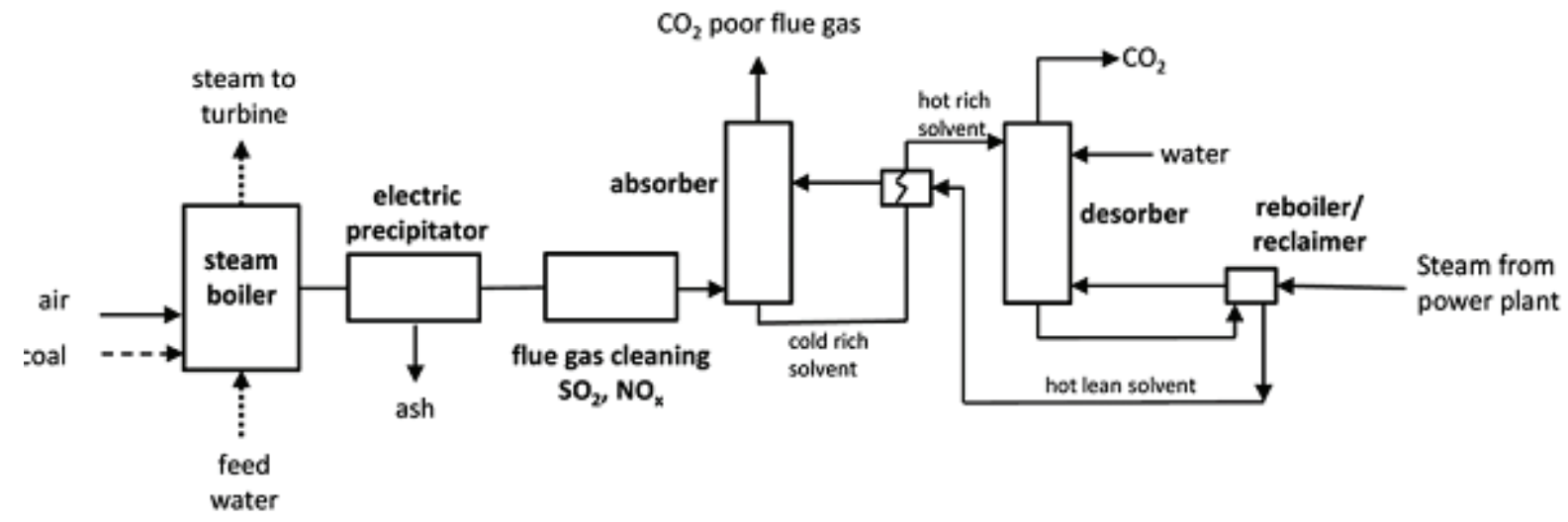

Figure 5. Integrated system for post combustion $\mathrm{CO}_{2}$ capture using amine washing. 


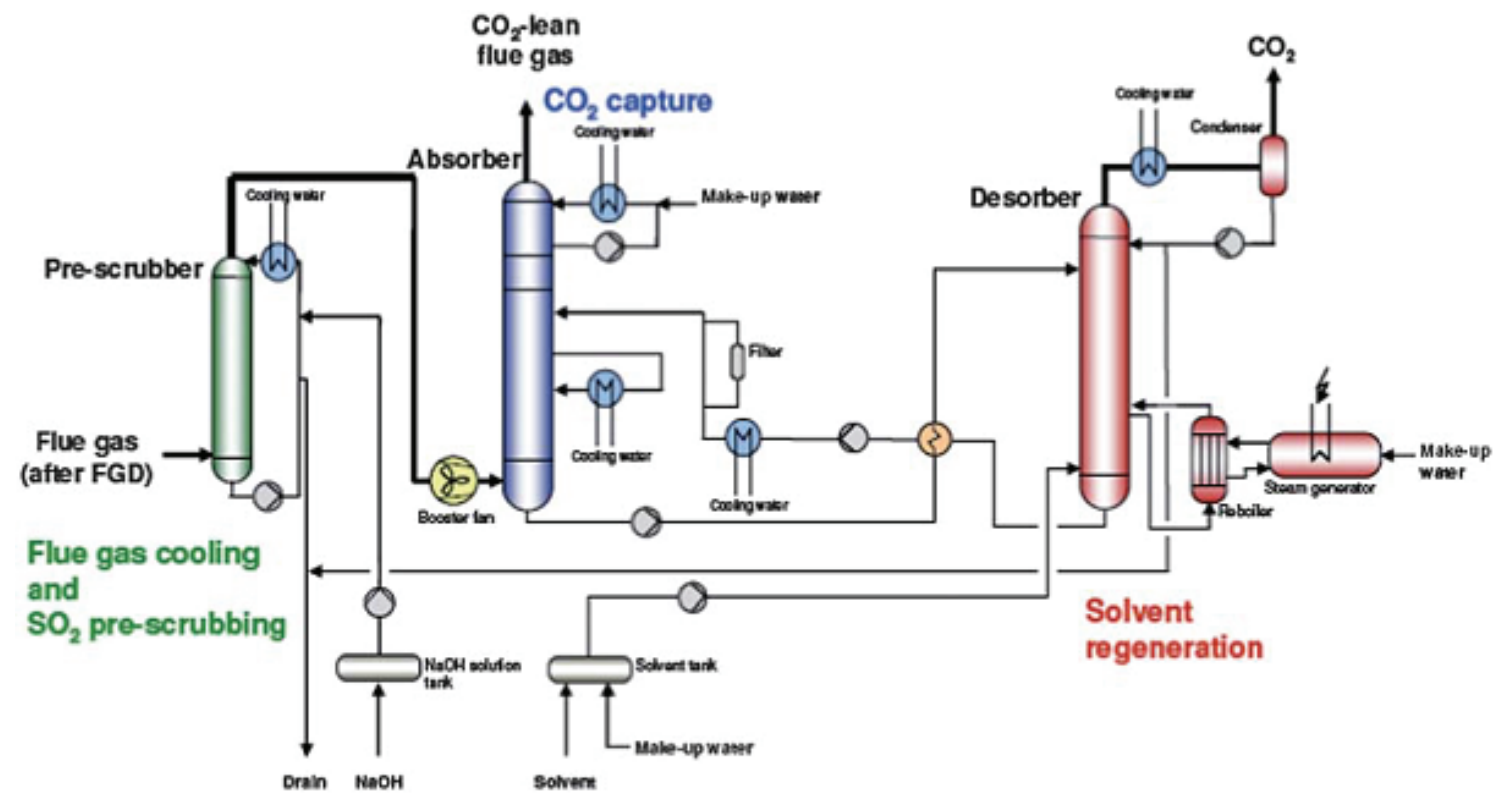

Figure 6. Niederaubem carbon dioxide capture facility.

from laboratory experiments. Large effort is being made toward determination of these properties, yet the correlation data is often used in design of process equipment.

In order to have accurate and reliable data for pure components, measurements of density and viscosity as the most important properties, and monitoring of their changes with temperature, were carried out herein.

Understanding of these properties is important from several points of view. Density and viscosity data and their changes with temperature have significant role in all balance equations. Accurate data can improve understanding of necessary requirements for industrial equipment, thus providing significant capital cost savings which may emerge from the reduction of used absorbents, height of absorber and striper columns, heat for sorbent regeneration etc.

Within the experimental section, thermodynamic and transport properties of four pure alkanolamines were investigated. The following pure chemicals were used: 1-amino-2-propanol (MIPA) (98\%), diisopropanolamine (DIPA) (98\%), diethanolamine (DEA) (99.5\%) all supplied by Merck and used without further purification. TIPA was supplied by Sigma Aldrich with purity higher than 95\%. Density measurements were performed using Anton Paar DMA 5000 digital vibrating $U$-tube densimeter (with automatic viscosity correction) and instrument accuracy $\pm 5 \times 10^{-3} \mathrm{~kg} \mathrm{~m}^{-3}$. Refractive index measurements were carried out using Anton Paar RXA 156 refractometer. Viscosities, $\eta$, of pure alkanolamines were measured using a digital Stabinger viscometer (model SVM 3000/G2). Detailed description of calibration, solution preparation, working methods of selected measuring equipment and information about measuring uncertainty, repeatability and reproducibility are given in our previous work [11-14].

\section{RESULTS AND DISCUSSION}

Experimental measurements were carried out in the temperature range from 288.15 to $333.15 \mathrm{~K}$ with temperature step of $5 \mathrm{~K}$. The density, refractive index and viscosity of MIPA, DIPA, TIPA and DEA alkanolamines were measured and compared with literature data, showing good agreement as presented in Table 1. Experimental data of the measured properties of four studied pure alkanolamines are presented in Figures 7-9.

Table 1. Review of the literature data for densities, refractive indices and viscosities of 1-amino-2-propanol (MIPA), diisopropanolamine (DIPA), triisopropanolamine (TIPA) and Diethanolamine (DEA)

\begin{tabular}{|c|c|c|c|c|c|c|}
\hline \multirow[t]{2}{*}{$T / \mathrm{K}$} & \multicolumn{2}{|r|}{$\rho / \mathrm{kg} \mathrm{m}^{-3}$} & \multicolumn{2}{|r|}{$n_{\mathrm{D}}$} & \multicolumn{2}{|r|}{$\eta / \mathrm{mPa} \cdot \mathrm{s}$} \\
\hline & This work & Literature & This work & Literature & This work & Literature \\
\hline \multicolumn{7}{|c|}{ MIPA } \\
\hline 293.15 & 960.625 & $\begin{array}{c}961.223[15], 960.38[16] \\
959.46[17]\end{array}$ & 1.44792 & $\begin{array}{l}1.4461[18] \\
1.44609[19]\end{array}$ & - & - \\
\hline 298.15 & 956.644 & $\begin{array}{c}957.114[15], 956.40[16], 956.3 \\
{[18], 956.51[20], 956.972[21]}\end{array}$ & 1.44590 & 1.44604 [22] & 23.259 & $\begin{array}{c}24.234[18], 26.685[19], \\
26.685[20], 23.00[21]\end{array}$ \\
\hline
\end{tabular}


Table 1. Continued

\begin{tabular}{|c|c|c|c|c|c|c|}
\hline \multirow[t]{2}{*}{$T / \mathrm{K}$} & \multicolumn{2}{|r|}{$\rho / \mathrm{kg} \mathrm{m}^{-3}$} & \multicolumn{2}{|c|}{$n_{\mathrm{D}}$} & \multicolumn{2}{|r|}{$\eta / \mathrm{mPa} \cdot \mathrm{s}$} \\
\hline & This work & Literature & This work & Literature & This wo & Literature \\
\hline \multicolumn{7}{|c|}{ MIPA } \\
\hline 303.15 & 952.641 & $952.980[15], 952.39[16], 952.52$ [20] & - & - & 17.702 & $20.314[20]$ \\
\hline 308.15 & 948.608 & $948.828[15], 948.36[16]$ & - & - & - & - \\
\hline 313.15 & 944.543 & $944.656[15], 944.30[16], 944.42$ [20] & - & - & 10.869 & $12.514[20]$ \\
\hline 318.15 & 940.449 & $940.462[15], 940.20[16]$ & - & - & - & - \\
\hline 323.15 & 936.322 & 936.244 [15], $936.08[16], 936.19$ [20] & - & - & 7.1156 & $7.543[20]$ \\
\hline 333.15 & - & - & - & - & 4.9475 & $5.220[20]$ \\
\hline \multicolumn{7}{|c|}{ DIPA } \\
\hline 313.15 & 992.460 & $991.99[21]$ & - & - & - & - \\
\hline 323.15 & 984.835 & $984.90[23]$ & - & - & 123.21 & $125.73[23], 125.20[24]$ \\
\hline 328.15 & 980.973 & $981.40[25]$ & - & - & 81.793 & $82.02[24]$ \\
\hline 333.15 & 977.040 & $976.98[21], 977.30[23]$ & - & - & 55.954 & $57.98[23], 55.91$ [24] \\
\hline 338.15 & 973.048 & $973.90[25]$ & - & - & 39.370 & $39.39[24]$ \\
\hline 343.15 & 969.008 & $969.58[23]$ & - & - & 28.572 & $29.55[23], 28.08$ [24] \\
\hline \multicolumn{7}{|c|}{ DEA } \\
\hline 293.15 & 1096.424 & $1097.250[15]$ & - & - & - & - \\
\hline 298.15 & 1093.221 & $1094.019[15], 1093.70[26], 1093.52[27]$ & 1.47640 & $1.4747^{21}$ & 566.57 & $566.30[28]$ \\
\hline 303.15 & 1089.989 & $\begin{array}{c}1090.778[15], 1090.89[28], 1089.4[29] \\
1089.84[30]\end{array}$ & - & - & 384.84 & $380.0[31]$ \\
\hline 308.15 & 1086.712 & 1087.508 [15], $1087.41[26], 1086.7$ [29] & - & - & - & - \\
\hline 313.15 & 1083.429 & $\begin{array}{c}1084.199[15], 1084.3[25], 1083.95[27] \\
1084.7[32], 1083.8[33], 1084.6[34] \\
1084.01[35]\end{array}$ & - & - & 189.86 & $188.80[28]$ \\
\hline 318.15 & 1080.221 & $1080.862[15]$ & - & - & - & - \\
\hline 323.15 & 1076.968 & $\begin{array}{c}1077.491[15], 1077.8[25], 1077.01[27] \\
1077.4[32], 1077.1[33], 1078.1[34] \\
1077.32[35]\end{array}$ & - & - & - & - \\
\hline 328.15 & 1073.670 & $1073.54[27]$ & - & - & - & - \\
\hline 333.15 & 1070.338 & $\begin{array}{c}1071.4[25], 1070.3[32], 1070.0[33], \\
1071.6[34], 1070.74[35]\end{array}$ & - & - & 58.407 & 57.69 [28] \\
\hline
\end{tabular}

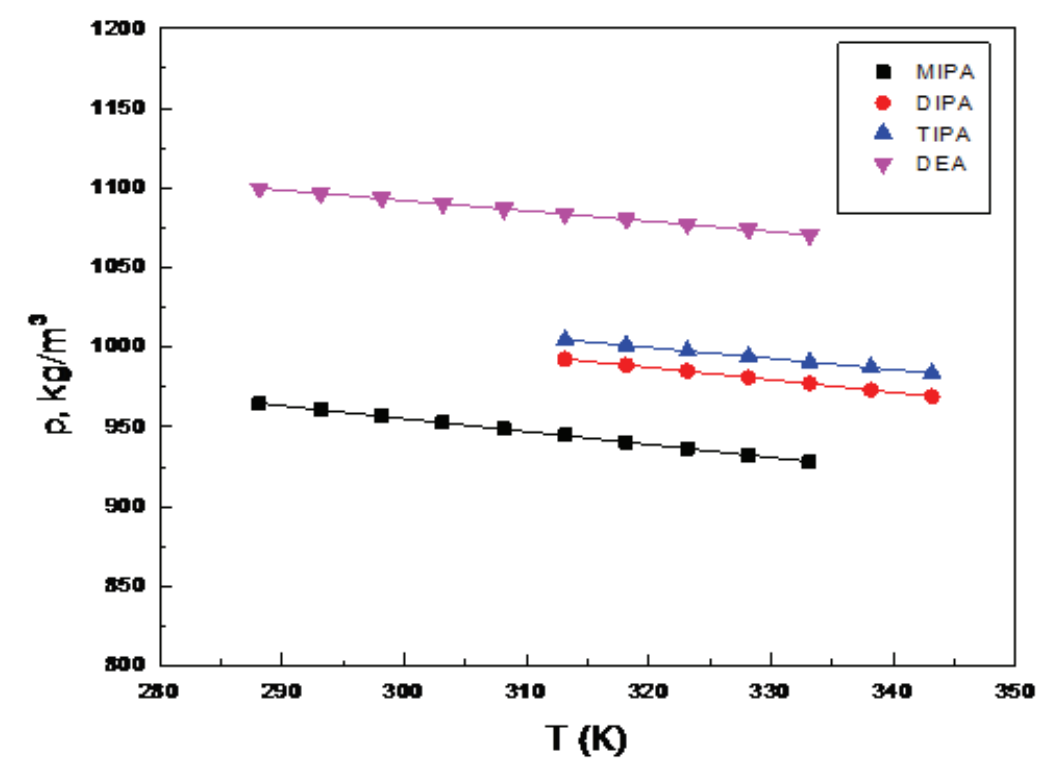

Figure 7. Densities of pure MIPA, DIPA, TIPA, and DEA at different temperatures and atmospheric pressure. 


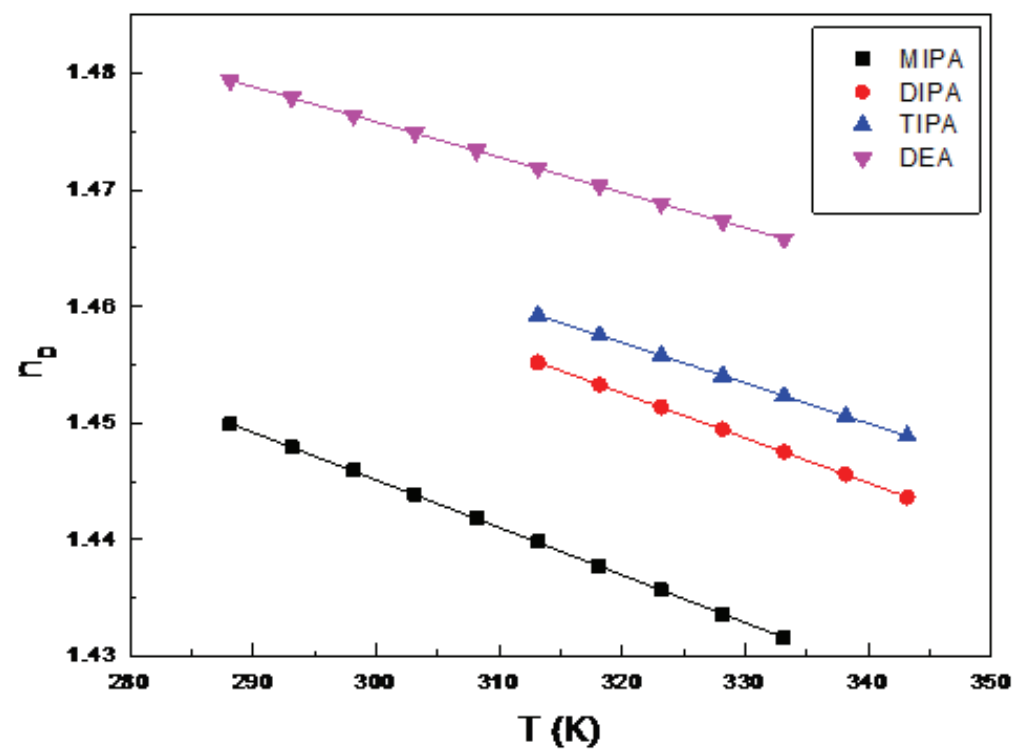

Figure 8. Refractive indices of pure MIPA, DIPA, TIPA, and DEA at different temperatures and atmospheric pressure.

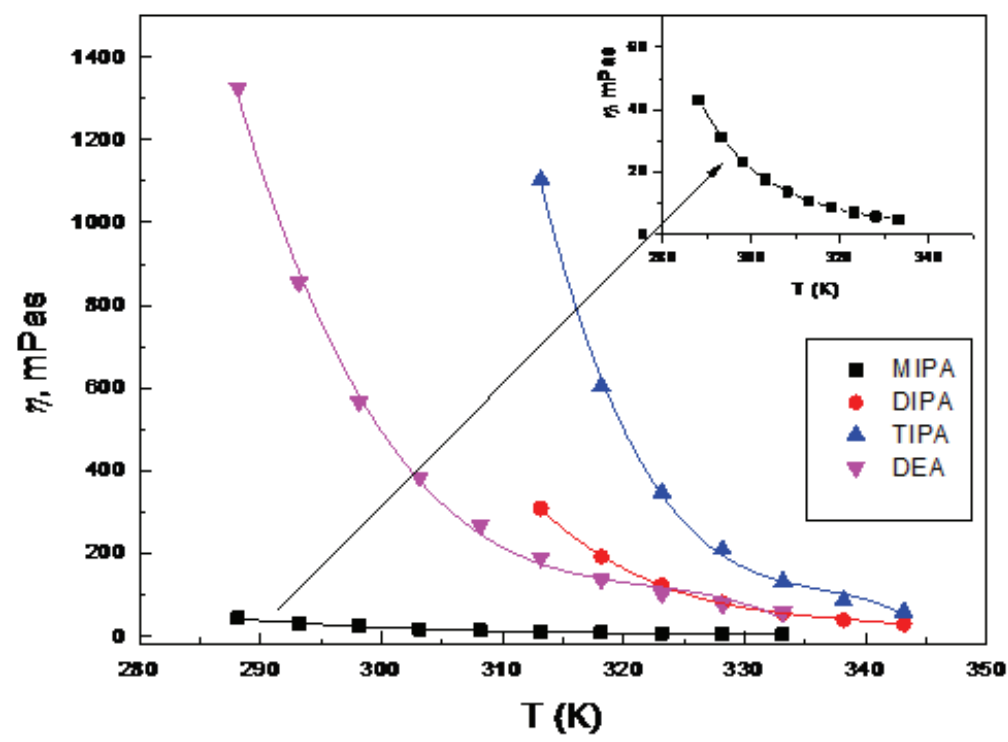

Figure 9. Viscosity of pure MIPA, DIPA, TIPA, and DEA at different temperatures and atmospheric pressure.

Density. Densities of four pure components were measured in temperature range from 288.15 to 333.15 K. Measured data shows linear temperature dependence of densities.
Refractive indices. The refractive indices almost linearly decrease with increase in temperature. The measured values of refractive index for all pure components are presented in Table 3.

Table 2. Densities $\left(\rho / \mathrm{kg} \mathrm{m}^{-3}\right)$ of pure MIPA, DIPA, TIPA and DEA at atmospheric pressure

\begin{tabular}{lcccc}
\hline$T / K$ & \multicolumn{3}{c}{ Compound } \\
\cline { 2 - 5 } & MIPA & DIPA & TIPA & DEA \\
\hline 288.1 & 964.573 & - & - & 1099.611 \\
293.15 & 960.625 & - & - & 1096.424 \\
298.15 & 956.644 & - & - & 1093.221 \\
303.15 & 952.641 & - & - & 1089.989 \\
308.15 & 948.608 & - & 1004.59 & 1086.712 \\
313.15 & 944.543 & 992.460 & 1083.429 \\
\hline
\end{tabular}


Table 2. Continued

\begin{tabular}{lcccc}
\hline \multirow{2}{*}{$T / \mathrm{K}$} & \multicolumn{3}{c}{ Compound } \\
\cline { 2 - 5 } & MIPA & DIPA & TIPA & DEA \\
\hline 318.15 & 940.449 & 988.611 & 1001.11 & 1080.221 \\
323.15 & 936.322 & 984.835 & 997.605 & 1076.968 \\
328.15 & 932.160 & 980.973 & 994.057 & 1073.670 \\
333.15 & 927.961 & 977.040 & 990.616 & 1070.338 \\
338.15 & - & 973.048 & 987.139 & - \\
343.15 & - & 969.008 & 983.626 & - \\
\hline
\end{tabular}

Table 3. Refractive indices, $n_{D}$, of pure MIPA, DIPA, TIPA and DEA at atmospheric pressure

\begin{tabular}{lcccc}
\hline$T / K$ & \multicolumn{3}{c}{ Compound } & DEA \\
\cline { 2 - 5 } & MIPA & DIPA & TIPA & 1.47939 \\
288.15 & 1.44992 & - & - & 1.47788 \\
293.15 & 1.44792 & - & - & 1.47640 \\
298.15 & 1.44590 & - & - & 1.47489 \\
303.15 & 1.44386 & - & - & 1.47340 \\
308.15 & 1.44185 & - & 1.45927 & 1.47188 \\
313.15 & 1.43980 & 1.45517 & 1.45754 & 1.47035 \\
318.15 & 1.43774 & 1.45330 & 1.45581 & 1.46883 \\
323.15 & 1.43568 & 1.45139 & 1.45405 & 1.46730 \\
328.15 & 1.43361 & 1.44946 & 1.45233 & 1.46578 \\
333.15 & 1.43162 & 1.44753 & 1.45061 & - \\
338.15 & - & 1.44559 & 1.44890 & - \\
343.15 & - & 1.44363 & & - \\
\hline
\end{tabular}

Viscosity. Viscosities of pure components decrease with increase in temperature. Experimental data are presented in Table 4.

\section{CONCLUSIONS}

Experimental determination of density, viscosity and refractive index of four alkanolamine reagents was carried out. $\mathrm{CO}_{2}$ capture technologies early developed for petrochemical industries application, are still in early phase of development regarding the treatment of flue gases in power plants. This paper presents main routes for the treatment of carbon capture with clear advantages, but also reveals the technical problems that need to be resolved. Due to economic limitations, it is clear that the focus in near future will be on increase of efficiency of already built power plants with

Table 4. Viscosities ( $\eta / m P a \cdot s)$ of pure MIPA, DIPA, TIPA and DEA at atmospheric pressure

\begin{tabular}{lcccc}
\hline \multirow{2}{*}{$/ \mathrm{K}$} & \multicolumn{3}{c}{ Compound } \\
\cline { 2 - 5 } & MIPA & DIPA & TIPA & DEA \\
\hline 288.15 & 43.032 & - & - & 1326.7 \\
293.15 & 31.238 & - & - & 855.25 \\
298.15 & 23.259 & - & - & 566.57 \\
303.15 & 17.702 & - & - & 384.84 \\
308.15 & 13.750 & - & 1103.4 & 267.51 \\
313.15 & 10.869 & 308.54 & 604.38 & 189.86 \\
318.15 & 8.7213 & 191.68 & 348.18 & 137.48 \\
323.15 & 7.1156 & 123.21 & 210.04 & 101.45 \\
328.15 & 5.8798 & 81.793 & 132.30 & 76.189 \\
333.15 & 4.9475 & 55.954 & 86.697 & 58.407 \\
338.15 & - & 39.370 & 59.186 & - \\
343.15 & - & 28.572 & & -
\end{tabular}


further delay in construction of new power plant units (IGCC). Concerning this, the amine based washing of flue gases will remain dominant technology in treatment of flue gases. Pre combustion processes, although effective, are still too expensive. Bearing in mind that number of currently installed units based on IGCC technology are below 10 , their contribution in reduction of total $\mathrm{CO}_{2}$ emission is low. In order to have "less expensive" $\mathrm{CO}_{2}$ removal technologies, storage of $\mathrm{CO}_{2}$ should be gradually replaced with further utilization of the removed $\mathrm{CO}_{2}$. New developments in the field of selective membranes, physical absorption and new energy efficient advanced absorbents, will further lower costs of flue gases treatment. Increase in energy demand will undoubtedly contribute to the emission of $\mathrm{CO}_{2}$, so implementation of all measures that are presented within this paper as standalone concept will not be sufficient.

\section{Acknowledgment}

The authors gratefully acknowledge the financial support received from the Research Fund of Ministry of Education, Science and Technological Development, Serbia, and the Faculty of Technology and Metallurgy, University of Belgrade (Project no. 172063).

\section{REFERENCES}

[1] IPCC, Carbon Dioxide Capture and Storage-Special Report of the Intergovernmental Panel on Climate Change, Cambridge University Press, Cambridge, 2005.

[2] J.Y. Park, S.J. Yoon, H. Lee, Effect of steric hindrance on carbon dioxide absorption into new amine solutions, Environ. Sci. Tecnol. 37 (2003) 1670-1675.

[3] A. Adisorn, V. Amornvadee, Characterization and comparison of the $\mathrm{CO}_{2}$ absorption performance into single and blended alkanolamines in a packed column, Ind. Eng. Chem. Res. 43 (2004) 2228-2237.

[4] K. Ariga, S. Ishihara, H. Abe, M. Li, P. Hill, Materials nanoarchitectonics for environmental remediation and sensing, J. Mater. Chem. 22 (2012) 2369-2377.

[5] M. Wietschel, M. Arens, C. Duotsch, S. Herkel, W. Krewitt, P. Markewitz, D. Muost, M. Scheufen, Energietechnologie 2050: Schwerpunkte fur Forschung und Entwicklung. Fraunhofer Verlag, Stuttgart, 2010.

[6] A. Kather, M. Klostermann, In Efficient Carbon Capture for Coal Power Plants, D. Stolten and V. Scheerer, Eds., Wiley-VCH Verlag, Weinheim, 2011, pp. 271-292.

[7] E. Kourosh, E. Zanganeh, A. Shafeen, C. Salvador, $\mathrm{CO}_{2}$ Capture and Development of pilot scale cryogenic separation and compression unit, Energy Procedia. 1 (2009) 247-252.

[8] B.A. Rao, S.E. Rubin, A technical, economic and environmental assessment of amine based $\mathrm{CO}_{2}$ capture technology for power plant greenhouse gas control, Environ. Sci. Technol. 36 (2002) 4467-4475.

[9] J. Rorkel, M. Seiler, Industrial progress: New energy efficient absorbents for the $\mathrm{CO}_{2}$ separation from natural gas, syngas and flue gas, Adv. Chem. Eng. Sci. 1 (2011) 280-288.

[10] P. Moser, S. Schmidt, G. Sieder, H. Garcia, I. Ciattaglia, H. Klein, Enabling post combustion capture optimizationthe pilot plant project at Niederaussem, Energy Procedia. 1 (2009) 807-814.

[11] V.D. Spasojević, S.P. Šerbanović, B.D. Djordjević, M.Lj. Kijevčanin, Densities, viscosities and refractive indices of aqueous alkanolamine solutions as potential carbon dioxide removal reagents, J. Chem. Eng. Data 58 (2013) 84-92.

[12] S.P. Šerbanović, M.Lj. Kijevčanin, I.R. Radović, B.D. Djordjević, Effect of temperature on the excess molar volumes of some alcohol + aromatic mixtures and modeling by cubic EOS mixing rules, Fluid Phase Equilib. 239 (2006) 69-82.

[13] M.Lj. Kijevčanin, M.M. Djuris, I.R. Radović, B.D. Djordjević, S.P. Šerbanović, Volumetric properties of the binary methanol + chloroform and ternary methanol + chloroform + benzene mixtures at 288.15, 293.15, 298.15, 303.15, 308.15 and 313.15 K, J. Chem. Eng. Data 52 (2007) 1136-1140.

[14] [14] M. Lj. Kijevčanin, I. R. Radović, E. M. Živković, B. D. Djordjević, S. P. Šerbanović, Influence of chain length and degree of branching of alcohol+chlorobenzene mixtures on determination and modelling of $\mathrm{V}^{\mathrm{E}}$ by CEOS and $\mathrm{CEOS} / \mathrm{G}^{\mathrm{E}}$ mixing rules, Fluid Phase Equilib. 263 (2008) 205-213.

[15] E. Alvarez, F. Cerdeira, D. Gomez-Diaz, M. Navaza, Density, speed of sound, isentropic compressibility, and excess volume of binary mixtures of 1-amino-2-propanol or 3-amino-1-propanol with 2-amino-2-methyl-1-propanol, diethanolamine, or triethanolamine from 293.15 to 323.15 K. J. Chem. Eng. Data 55 (2010) 2567-2575.

[16] S. Mokraoui, A. Valtz, C. Coquelet, D. Richon, Volumetric properties of the isopropanolamine-water at atmospheric pressure from 283.15 to $353.15 \mathrm{~K}$, Thermochim. Acta 440 (2006) 122-128.

[17] H. Herba, G. Czechowski, B. Zywucki, M. Stockhausen, J. Jadzyn, Molar Excess Volumes of Binary Mixtures of Amino Alcohols with 1,4-Dioxane, J. Chem. Eng. Data. 40 (1995) 214-215.

[18] D. Gomez-Diaz, M. Dolores La Rubia, A. Lopez, J. Navaza, R. Pacheco, S. Sanchez, Density, Speed of sound, refractive index, and viscosity of 1-amino-2-propanol for bis(2-hydroxypropyl)amine + triethanolamine + water from $t=288.15$ to $333.15 \mathrm{~K}$, J. Chem. Eng. Data 57 (2012) 1104-1111.

[19] Y. Maham, N. C. Liew, E. A. Mather, Viscosities and excess properties of aqueous solutions of ethanolamines from 25 to $80{ }^{\circ} \mathrm{C}$, J. Solution Chem. 31 (2002) 743-756.

[20] V. Rayer, S. Kadiwala, K. Narayanaswamy, A. Henni, Volumetric properties, viscosities and refractive indices for aqueous 1-amino-2-propanol (monoisopropanolamine (mipa)) solutions from 298.15 to $343.15 \mathrm{~K}$, J. Chem. Eng. Data 55 (2010) 5562-5568.

[21] The Alkanolamines Handbook, Dow Chemical Company, Midland, MI, 1981. 
[22] R.R. Dreisbach, Physical properties of chemical compounds III, American Chemical Society, Washington D.C., 1961.

[23] A. Henni, J. Hromek, P. Tontiwachwuthikul, A.Chakma, Volumetric properties and viscosities for aqueous diisopropanolamine solutions from $25^{\circ} \mathrm{C}$ to $70{ }^{\circ} \mathrm{C}$, J. Chem. Eng. Data 48 (2003) 1062-1067.

[24] J.J. Ko, T.C. Tsai, C.Y. Lin, H.M. Wang, M.H. Li, Diffusivity of nitrous oxidein aqueous alkanolamine solutions, J. Chem.Eng. Data 46 (2001) 160-165.

[25] W.Y. Wang, S. Xu, D.F. Otto, E.A. Mather, Solubility of $\mathrm{N}_{2} \mathrm{O}$ in alkanolamines and in mixed solvents, Chem. Eng. J. 48 (1992) 31-40.

[26] B. Hawrylak, E.S. Burke, R. Palepu, Partial molar and excess volumes and adiabatic compressibilities of binary mixtures of ethanolamines with water, J. Solution Chem. 29 (2000) 575-594.

[27] F. Murrieta-Guevara, A.T. Rodriguez, Liquid density as a function of temperature of five organic solvents, J. Chem. Eng. Data 29 (1984) 204-209.

[28] T.T. Teng, Y. Maham, L.G. Hepler, A.E. Mather, Viscosity of aqueous solutions of $n$-methyldiethanolamine and of diethanolamine, J. Chem. Eng. Data 39 (1994) 290-293.

[29] J. Aguila-Hernandez, A. Trejo, E.B. García-Flores, R. Molna, Viscometric and volumetric behaviour of binary mixtures of sulfolane and $\mathrm{N}$-methylpyrrolidone with monoethanolamine and diethanolamine in the range 303-373 K, Fluid Phase Equilib. 267 (2008) 172-180.

[30] J.A. Riddick, W.B. Bunger, Organic Solvents: Physical Properties and Methods of Purification, $3^{\text {rd }}$ ed., Wiley Interscience, New York, 1970.

[31] Ethanolamines, Product Data, Olin Chemicals, Stamford, CT, 1980.

[32] J. Aguila-Hernandez, R. Gomez-Quintana, F. Murrieta-Guevara, A. Romero-Martınez, A. Trejo, Liquid density of aqueous blended alkanolamines and $\mathrm{N}$-methylpyrrolidone as a function of concentration and temperature, J. Chem. Eng. Data 46 (2001) 861-867.

[33] F. Murrieta-Guevara, A. Trejo, Liquid density as a function of temperature of five organic solvents, J. Chem. Eng. Data 29 (1984) 204-206.

[34] M.R. DiGuilio, J.R. Lee, T.S. Schaeffer, L.L. Brasher, S.A. Teja, Densities and viscosities of the ethanolamines, J. Chem.Eng. Data 37 (1992) 239-242.

[35] Y. Maham, T.T. Teng, G.L. Hepler, E.A. Mather, Densities, excess molar volumes, and partial molar volumes for binary mixtures of water with monoethanolamine, diethanolamine, and triethanolamine from 25 to $80{ }^{\circ} \mathrm{C}$, J. Solution Chem. 23 (1994) 195-205. 


\section{IZVOD}

\section{PREGLED TEHNOLOŠKIH POSTUPAKA I EKSPERIMENTALNO ODREĐIVANJE TERMODINAMIČKIH I TRANSPORTNIH SVOJSTAVA REAGENSA ZA UKLANJANJE UGLJEN-DIOKSIDA}

Vuk D. Spasojević ${ }^{1}$, Slobodan P. Šerbanović ${ }^{2}$, Predrag Stefanović ${ }^{1}$, Mirjana Lj. Kijevčanin ${ }^{2}$

${ }^{1}$ Institut za nuklearne nauke „Vinča“, Univerzitet u Beogradu, Mike Petrovića Alasa 12-14, Beograd, Srbija

${ }^{2}$ Tehnološko-metalurški fakultet, Univerzitet u Beogradu,Karnegijeva 4, Beograd, Srbija

(Naučni rad)

Intezivna naučna istraživanja u proteklih dvadeset godina pružaju jasne dokaze da su klimatske promene, kao i porast koncentracije gasova koji izazivaju efekat staklene bašte $u$ atmosferi, prouzrokovane čovekovim delovanjem. Energetski sektor igra ključnu ulogu u ukupnoj emisiji ugljen-dioksida sa udelom između 60 i 70\%, obaveza po pitanju smanjenja emisije gasova staklene bašte. Pored toga, povećanje potrošnje energije iz godine u godinu, kao i očekivano povećanje industrijske proizvodnje, dovešće do povećanja potrošnje fosilnih goriva, a samim tim i do povećanja emisije gasova staklene bašte. Navedene činjenice impliciraju da će energetski sektor biti ključan sektor u kome je potrebno ostvariti implementaciju svih mera i aktivnosti koje kao glavni cilj imaju smanjenje emisije gasova staklene bašte. Ovaj rad daje pregled tehnoloških postupaka za uklanjanje ugljen-dioksida od kojih su neki već našli komercijalnu upotrebu, dok su drugi još uvek u fazi razvoja. Posebna pažnja je posvećena opisu metoda zasnovanih na hemisoprpciji rastvora alkanolamina, koji su našli široku komercijalnu upotrebu. Izbor odgovarajućeg rastvarača, procesne opreme, radnih parametara, procesa sagorevanja itd. su samo neki od ključnih tačaka koje su prikazane u okviru ovog rada sa ciljem pružanja jasnije slike o mogućnostima i ograničenjima metoda za uklanjanje ugljen-dioksida. U okviru eksperimentalnog dela rada dati su rezultati merenja transportnih svojstava, nedovoljno ispitanih jedinjenja monoizopropanolamina (MIPA), diizopropanolamina (DIPA), triizopropanolamina (TIPA) i dietanolamina (DEA) kao potencijalnih reagensa za uklanjanje ugljen-dioksida. Od posebnog interesa su svojsta gustine, indeksa refrakcije i viskoznosti kao i promena ovih svojstava čistih jedinjenja sa temperaturom. Navedeni parametri su ključni za projektovanje procesne opreme kao i za optimizaciju samog procesa uklanjanja ugljen-dioksida.
Ključne reči: Gustina • Viskoznost • Indeks refrakcije - Uklanjanje ugljen-dioksida • Hemisorpcija • Dimni gasovi • Alkoholamini 